\title{
OMNIBUS LAW DALAM TINJAUAN HIFDZUL MAL
}

\author{
Mohammad Farid Fad \\ UIN Walisongo Semarang, Indonesia \\ mohammadfarid@walisongo.ac.id
}

Received:13-01-2020; Revised:21-04-2020; Accepted: 11-06-2020;

\section{ABSTRACT}

The government has initiated the omnibus law nomenclature which was triggered by the overlapping and disharmonious implementation of laws and regulations regarding licencing in various sectors which aims at resolving business licencing constraints to lure investors and resolve taxation issues in Indonesia. However, the implementation of omnibus law needs to be reviewed on its benefits in perspective of maqashid syari'ah particularly hifdzul mal concept mainly related to the effectiveness of using the budget to create a conducive tax and investment climate. The qualitative method was used in this research. Descriptive-analytical method was then used to analyze collected data. The results showed that the purpose of establishing omnibus law is to fulfil an urgent need for a concise solution to conflicting laws and regulations, both vertically and horizontally for the benefits and consistency of such conflicting laws. Omnibus law is needed in order to maintain the stability of the State's economy (hifdzul mal) since it is time consuming and costly to address the laws one by one.

Keywords: Omnibus Law, Maqashid Syariah and Hifdzul Mal

\section{INTISARI}

Belakangan ini, nomenklatur omnibus law digagas oleh pemerintah yang bermula dari fenomena tumpang tindihnya atau disharmoni peraturan perundang-undangan yang disebut di atas yaitu terkait perizinan di berbagai sektor, yang bertujuan untuk menyelesaikan hambatan perizinan usaha sehingga menarik para investor untuk menanamkan investasinya dan persoalan perpajakan di Indonesia. Namun penggunaan omnibus law ini perlu ditinjau dari sisi kemaslahatannya, dalam perspektif maqashid syari'ah, khususnya konsep hifdzul mal, utamanya terkait efektivitas penggunaan anggaran demi tercapainya iklim investasi dan perpajakan yang kondusif. Jenis metode yang dipakai dalam penelitian ini adalah metode kualitatif. Setelah data terkumpul, akan dilakukan analisis dengan menggunakan metode deskriptif-analitis. Hasil penelitian menunjukkan bahwa tujuan dari pembentukan RUU Omnibus Law adalah dikarenakan ada kebutuhan mendesak untuk teknik merumuskan undang-undang yang mengubah lebih dari satu peraturan yang relevan, demi menciptakan kemaslahatan dan konsistensi berbagai undangundang. Omnibus law diperlukan karena berdasarkan pertimbangan kemaslahatan demi menjaga kestabilan perekonomian Negara (hifdzul mal), sebab bila dibenahi satu persatu maka akan memerlukan waktu yang lama dan biaya yang banyak.

Kata Kunci: Omnibus Law, Maqashid Syariah dan Hifdzul Mal

\section{A. Pendahuluan}

Berfungsinya peraturan perundangan secara efektif dan efisien merupakan salah satu elemen terpenting konsep Negara hukum (rechtstaats) dalam era demokrasi modern. Perundangundangan dalam arti luas tidak hanya berisi muatan norma-norma hukum, namun juga sarat 
muatan filosofis dan sosiologis yang berdampak pada terwujudnya kepastian hukum, kemanfaatan dan keadilan hukum demi sehatnya iklim demokrasi suatu Negara.

Dalam tradisi hukum civil law ${ }^{1}$ klasik, perundang-undangan merupakan manifestasi dari supremasi lembaga perwakilan rakyat (legislative body supremacy) yang juga merupakan simbol perwakilan rakyat. Namun dalam konteks kontemporer, negara-negara civil law sudah mulai mengakomodir pentingnya peranan yurisprudensi (precedents) dalam sistem hukum mereka. Fenomena yang sama juga terjadi di negara-negara common law $w^{2}$ yang juga telah memberikan porsi yang seimbang kepada peraturan perundangan (statutory law). Dalam konteks perbandingan hukum tata negara, sekat imajiner antara kedua tradisi dan sistem hukum tersebut sudah sedemikian longgar ${ }^{3}$.

Sebagai salah satu sub-sistem dari negara hukum, peraturan perundang-undangan dicitrakan mampu menjawab segala persoalan hukum kebangsaan yang berhubungan dengan kepentingan politisi (Parpol) di sidang parlemen. Perundang-undangan dianggap sebagai produk hukum yang diklaim "obyektif” karena dibuat dalam proses dan teknik penyusunan yang taat asas hukum (rechtsbeginsel), oleh lembaga perwakilan rakyat. Hingga perundang-undangan didefinisikan sebagai: "Peraturan perundangan adalah peraturan tertulis yang memuat norma hukum yang mengikat secara umum dan dibentuk atau ditetapkan oleh lembaga Negara atau pejabat yang berwenang melalui prosedur yang ditetapkan dalam Peraturan Perundangundangan". 4

Namun ironisnya, dalam tataran realitasnya, alih-alih memberi jaminan kepastian hukum (legal certainty) bagi masyarakat, peraturan perundang-undangan di Indonesia sering memberi ketidakpastian hukum (legal uncertainty), disebabkan banyaknya peraturan yang tumpang tindih (overlapping) baik dalam tingkatan hierarki yang sama ataupun peraturan yang berada di bawahnya. Di antaranya sektor Sumber Daya Alam (SDA) yang berkaitan dengan kemudahan berinvestasi: UU Nomor 41 Tahun 1999 tentang Kehutanan, UU Nomor 32 Tahun 2009 tentang Perlindungan dan Pengelolaan Lingkungan Hidup (PPLH) dan UU Nomor 5 Tahun 1960 tentang Peraturan Dasar Pokok-Pokok Agraria.

Sementara belakangan ini, nomenklatur omnibus law banyak dikemukakan oleh pemerintah dan didiskusikan para ahli. Fenomena ini tepatnya muncul setelah pidato pelantikan Presiden Jokowi (20/10) di Gedung DPR MPR DPD RI, selain itu juga merespon iklim investasi

1 Ciri Negara civil law ialah adanya sistem kodifikasi, hakim tidak terikat dengan preseden atau doktrin stare decicis, sehingga undang-undang menjadi rujukan hukumnya yang utama, sistem peradilannya bersifat inkuisitorial. Nurul Qamar. 2010. Perbandingan Sistem Hukum dan Peradilan Civil Law System dan Common Law System,. (Makassar: Pustaka Refleksi), 40.

${ }^{2}$ Ciri Negara penganut common law ialah yurisprudensi sebagai sumber hukum utama, dianutnya doktrin Stare Decicis/Sistem Preseden, dan Adversary System dalam proses peradilan. Nurul Qamar. 2010. Perbandingan Sistem Hukum ........, 47.

${ }^{3}$ Andrian Bedner, Indonesia Legal Scholarship and Jurisprudence as an Obstacle for Transplanting Legal Institutions, Hague Journal of the Rule of Law 5 (2013), 235-273.

${ }^{4}$ Pasal 1 Ayat 2 UU Nomor 12 Tahun 2011 tentang Pembentukan Peraturan Perundangan. 
sampai saat ini kurang menunjukkan angka yang optimis untuk mencapai target yang diharapkan, apalagi menghadapi resesi ekonomi dunia imbas perang dagang AS-China 2020.

Badan Koordinasi Penanaman Modal (BKPM) mencatat realisasi investasi Penanaman Modal Dalam Negeri (PMDN) dan Penanaman Modal Asing (PMA) pada kuartal 1/2019 (Januari-Maret) mencapai angka sebesar Rp 195,1 triliun. Angka tersebut naik 5,3\% dibanding periode yang sama pada 2018 yang sebesar Rp 185,3 triliun ${ }^{5}$.

Sebenarnya, gagasan ini berawal dari fenomena tumpang tindihnya atau disharmoni peraturan perundang-undangan yang disebut di atas yaitu terkait perizinan di berbagai sektor, yang bertujuan untuk menyelesaikan hambatan perizinan usaha sehingga menarik para investor untuk menanamkan investasinya di Indonesia. Demi memenuhi target tersebut, pemerintah harus merombak besar-besaran pasal-pasal yang terkait perizinan di bidang investasi yang meliputi 72 undang-undang lewat satu terobosan undang-undang baru (omnibus law), yang diharapkan punya daya jangkau yang luas.

Namun penggunaan omnibus law ini perlu ditinjau dari sisi kemaslahatannya, utamanya terkait efektivitas penggunaan anggaran demi tercapainya iklim investasi dan perpajakan yang kondusif. Dalam hal ini, kebijakan omnibus law dikaji dalam perspektif maqashid syari'ah, khususnya konsep hifdzul mal. Dari uraian tersebut timbul permasalahan yang akan diteliti yaitu bagaimanakah omnibus law dalam tinjauan hifdzul mal?

\section{B. Metode Penelitian}

Jenis metode yang dipakai dalam penelitian ini adalah metode kualitatif. Hal ini disebabkan oleh apa yang dilakukan dalam penelitian ini yang tidak bertujuan untuk mengukur hubungan antar variable, akan tetapi bertujuan untuk menganalisis omnibus law dalam tinjauan hifdzul mal. Setelah data terkumpul, akan dilakukan analisis dengan menggunakan metode deskriptif-analitis, yaitu menggambarkan secara sistematis fakta yang ditemukan secara akurat dan cermat, serta dilakukan analisis secara kualitatif guna mendapatkan pemahaman terhadap problem yang diteliti secara lebih mendalam.

\section{Hasil dan Pembahasan}

\section{Omibus Law dalam Sejarah}

Pada dasarnya, hukum merupakan norma-norma yang bersifat mengikat dan memaksa dimana mengatur perilaku manusia yang dibentuk oleh lembaga yang berwenang. Dalam koridor negara hukum, hukum dibuat guna menegakkan keadilan dan melindungi harkat manusia.

Pasal 1 ayat (3) UUD NRI Tahun 1945 telah mendeklarasikan bahwa Negara Indonesia adalah negara berdasarkan hukum (rechtstaats), dan bukan negara yang berdasarkan kekuasaan (machtsstaat). Dengan dasar tersebut, menyatakan bahwa setiap warga negara wajib mengikuti serta mentaati aturan perundangan yang berlaku.

A.V. Dicey menjelaskan adanya 3 unsur penting dalam setiap negara hukum yang disebutnya dengan istilah "The Rule of Law", yaitu6 :

${ }^{5}$ Oktiani Endarwati, https://www.bkpm.go.id/, diakses 12/12/2019, pukul 19.34 WIB

${ }^{6}$ Hadjon, Philiphus M, 2007, Perlindungan Hukum Bagi Rakyat di Indonesia, Sebuah Studi tentang Prinsip-Prinsipnya, Penanganannya oleh Pengadilan dalam Lingkungan Peradilan Umum dan Pembentukan Peradilan Administrasi, Peradaban, 75. 


\section{Supremacy of law;}

2. Equality before the law yaitu persamaan di hadapan hukum;

3. Due process of law atau terjaminnya hak-hak manusia oleh konstitusi.

Namun dalam realitanya, peraturan perundangan bisa saja tidak berfungsi secara maksimal dikarenakan terjadi tumpang tindih antar peraturan dalam domain yang sama. Disharmoni peraturan perundang-undangan ini bisa saja terjadi dikarenakan egoisme sektoral dalam proses pembentukan dan perencanaan hukum.

Akan tetapi tak sedikit aturan hukum yang bertentangan satu sama lain, aturan itu juga mengatur hal yang sama dengan cara berbeda-beda, problem tersebut ujungnya menjadi penghambat berbagai percepatan. Untuk itu, diperlukan langkah harmonisasi peraturan perundangan. Istilah harmonisasi peraturan perundangan lebih menekankan pada keberadaan indikator-indikator dan karateristik yang sama dalam sebuah peraturan.

Demi mengurai kekusutan hukum tersebut, diperlukan upaya mentransplantasi konsep omnibus law yang lahir dari tradisi common law. Konsep ini pernah diusulkan dalam konteks regulasi pertanahan guna penyelesaian carut marut regulasi pertanahan lewat skema pembentukan Peraturan Pemerintah Pengganti Undang-undang (Perpu) ${ }^{7}$.

Disadari bahwa problem yang sering muncul saat ini dalam proses pembentukan hukum kental sekali bermuatan politis. Inilah yang menyebabkan produk perundang-undangan yang ada seolah cacat sejak lahir. Hingga terkesan banyak aturan yang masing-masing tumpang tindih, tidak harmoni satu sama lain. Aturan yang harusnya menciptakan keteraturan justru mempersulit diri sendiri dengan membawa akibat ketidakteraturan. Untuk memperbaikinya-pun tentu membutuhkan biaya, waktu, tenaga dan proses yang cukup rumit seperti halnya pengajuan judicial review ke Mahkamah Konstitusi.

Belum lagi proses perancangan draft peraturan perundang-undangan di meja legislatif yang seringkali berbelit-belit hingga menemui jalan buntu akibat konflik kepentingan partai politik. Efeknya secara langsung ialah pemborosan anggaran Negara untuk membiayai proses legislasi.

Untuk itu diperlukan upaya terobosan hukum dari Pemerintah sebagai legislator bersama DPR dalam rangka menyelesaikan permasalahan regulasi yang menghambat investasi dan gurita problem perpajakan. Melalui omnibus law, persoalan tumpang tindihnya peraturan perundangan yang menghambat pertumbuhan ekonomi diperkirakan akan menurun.

Sebenarnya, secara historis, perkembangan dan perdebatan perbandingan Hukum Tata Negara sebagai sebuah pendekatan metodis dapat dilacak dalam sejarah perkembangan Hukum Tata Negara di Amerika Serikat. Putusan kasus Printz v, United States menjadi justifikasi akademik dari penggunaan perbandingan hukum, Hakim Breyer dalam dissenting opinion-nya menyatakan penting suatu Negara meminjam, mengadopsi atau mentransplantasi putusan pengadilan dan struktur hukum Negara lain, dalam Breyer menyatakan bahwa tidak ada solusi

${ }^{7}$ Firman Freaddy Busroh, Konseptualisasi Omnibus Law Dalam Menyelesaikan Permasalahan Regulasi Pertanahan, Jurnal ARENA HUKUM, Volume 10, Nomor 2, Agustus 2017, 233. 
yang sepenuhnya berbeda dalam menyelesaikan permasalahan hukum, setiap Negara dapat mengambil pola umum (big pattern) dalam setiap konteks permasalahan ${ }^{8}$.

Namun dissenting opinion Hakim Breyer ditanggapi dingin oleh ketua majelis hakim saat itu, Hakim Scalia, yang menyatakan bahwa federalism Amerika Serikat bukanlah seperti Uni Eropa, karena setiap Negara memiliki akar historis dan tradisi yang berbeda, yang secara signifikan berpengaruh pada tata hukum suatu bangsa (the American law is deeply rooted in that country's history and traditions $)^{9}$. Setidaknya, pertentangan pendapat antar hakim tersebut telah membuka kotak Pandora tentang transplantasi hukum (legal transplant) dan partikularisme hukum yang diiringi dengan relativisme budaya.

Dalam konteks sejarah dan tradisi hukum common law, omnibus law dapat ditafsirkan sebagai upaya mereformasi hukum guna merubah dan kemudian memunculkan norma hukum baru yang bertujuan menegasikan norma-norma hukum sebelumnya dalam beberapa UU dengan hanya lewat satu UU saja ${ }^{10}$.

Duhaime Legal Dictionary mendefinisikan omnibus law sebagai berikut: "A bill (or law) which contains more than one substantive matter, or several minor matters which have been combined into one bill (law), ontensibly for the sake of confenience". ${ }^{11}$ Consice Australian Legal Dictionary memberi pengertian sebagai berikut; "An act of Parliament that makes amendements to a number of different Acts" 12

Omnibus law bukanlah hal baru di dunia ilmu hukum secara global. Kebijakan ini pernah dilakukan di hukum Serbia yang diadopsi pada tahun 2002 yang mengatur status otonom Provinsi Vojvodina yang termasuk di dalam Serbia ${ }^{13}$. Praktek omnibus law juga pernah dipraktekkan Irlandia guna perampingan peraturan perundangan yang menghapus sekitar 3.225 Undang-Undang lewat satu UU omnibus law. Capaian Irlandia dianggap sebagai satu rekor dunia praktek omnibus $l a w^{14}$.

O'Brien dan Bosc (2009) menyatakan bahwa omnibus law berupaya untuk mengubah, mencabut, atau memberlakukan beberapa undang-undang, dan dicirikan oleh fakta bahwa ia memiliki sejumlah aturan terkait tetapi terpisah. Intinya adalah perbaikan dari beberapa aturan sebelumnya ${ }^{15}$.

Omnibus law diperlukan karena berdasarkan pertimbangan kemaslahatan demi menjaga kestabilan perekonomian Negara, sebab bila hendak dibenahi satu persatu maka akan

${ }^{8}$ Mirza Satria Buana, SH., MH., Ph.D., Menakar Konsep Omnibus Law dan Consolidation Law Untuk Harmonisasi Peraturan Perundang-undangan Indonesia: Pendekatan Perbandingan Hukum Tata Negara, Prosiding Konferensi Nasional Hukum Tatat Negara ke-4, 10-13 November 2017, (UPT Penerbitan Universitas Jember), 306.

${ }^{9}$ Mirza Satria Buana, SH., MH., Ph.D., Menakar Konsep Omnibus Law........., 306.

${ }^{10}$ Louis Massicotte, Omnibus Law in Theory and Practice, Canadian Parliamentary Review, 2013, 13-17.

${ }^{11}$ Duhaime Legal Dictionary, http://www.duhaime.org/LegalDictionary/O/OmnibusBill.aspx

${ }^{12}$ Peter Butt and David Hamer, Consice Australian Legal Dictionary, (LexisNexis, $4^{\text {th }}$ ed, 2011), 413.

${ }^{13}$ Firman Freaddy Busroh, Konseptualisasi Omnibus Law..........., 241.

${ }^{14}$ Louis Massicotte, Omnibus Law in ..............., 25-31.

${ }^{15}$ Ibid., 13. 
memerlukan waktu yang cukup lama dan biaya yang tidak sedikit. Banyaknya aturan tersebut membuat kecepatan sikap pemerintah mengambil keputusan menjadi lambat. Persoalan berbelitnya regulasi menjadi salah satu faktor utama pemicu melambatnya iklim investasi di Indonesia, disbanding negara-negara tetangga seperti Malaysia dan Singapura.

Untuk menata ulang semua persoalan hukum akibat regulasi yang berbelit terkait perpajakan dan investasi maka menjadi suatu keharusan untuk melakukan reformasi regulasi dibidang tersebut. Diharapkan, melalui kebijakan omnibus law yang nanti bisa diwujudkan dalam bentuk peraturan terpadu (omnibus regulation) akan meminimalisir benturan peraturan perundang-undangan yang terkait perpajakan dan penanaman investasi dan perpajakan. Omnibus law dimaksudkan menjadi sebuah revolusi hukum yang berfungsi sebagai UU sapu jagat guna mengatasi problem hiper-regulasi tersebut.

Omnibus law dapat diberlakukan untuk mengubah lebih dari satu UU jika ${ }^{16}$ :

(a) perubahan (amandemen) berhubungan dengan topik yang saling terkait yang dapat dianggap sebagai penerapan kebijakan tunggal.

(b) perubahan (amandemen) yang akan dilakukan untuk masing-masing Undang-undang memiliki sifat serupa di setiap kasus.

Pendeknya, omnibus law merupakan suatu UU yang dibuat untuk menyasar satu isu besar yang mungkin dapat mencabut atau mengubah beberapa UU sekaligus. Konsep ini juga dikenal dengan omnibus bill yang sering digunakan di Negara yang menganut sistem anglo saxon guna membuat satu UU baru untuk mengamandemen beberapa UU sekaligus ${ }^{17}$.

Dengan upaya omnibus law maka peraturan yang dianggap tidak relevan atau bermasalah diharapkan dapat diselesaikan secara cepat dan tepat. Setidaknya ada beberapa kelebihan penerapan konsep omnibus law dalam menyelesaikan sengketa regulasi di Indonesia antara lain ${ }^{18}$ :

1) Mengatasi konflik peraturan perundang-undangan secara cepat, efektif dan efisien.

2) Menyeragamkan kebijakan pemerintah baik di tingkat pusat maupun didaerah untuk menunjang iklim investasi;

3) Pengurusan perizinan lebih terpadu, efisien dan efektif;

4) Mampu memutus rantai birokrasi yang berlama-lama;

5) Meningkatnya hubungan koordinasi antar instansi terkait karena telah diatur dalam kebijakan omnibus regulation yang terpadu

6) Adanya jaminan kepastian hukum (rechtszekerheid) dan perlindungan hukum bagi pengambil kebijakan.

16 Adam M. Dodek, Omnibus Bills: Constitutional Constraints and Legislative Liberations, Ottawa Law Review, Vol. 48, No. 1, 2017, 24.

${ }^{17}$ Henry Donald Lbn. Toruan, Pembentukan Regulasi Badan Usaha Dengan Model Omnibus Law, Jurnal Hukum Tora Fakultas Hukum Universitas Kristen Indonesia, Vol. 3 No. 1, April 2017, 464.

${ }^{18}$ Firman Freaddy Busroh, Konseptualisasi Omnibus Law,............, 21. 
Dalam prakteknya, ada tiga tahapan proses pembuatan RUU omnibus law ${ }^{19}$ :

1) Satu atau lebih dari satu hukum atau peraturan adalah atau sedang dibatalkan.

2) Hanya ketentuan hukum atau peraturan khusus yang telah berlaku dicabut atau diamandemen, sementara seluruh hukum atau peraturan yang bersangkutan tetap efektif.

3) Dalam hal ini memungkinkan banyak undang-undang atau aturan di berbagai domain direvisi asalkan terkait dalam beberapa tema yang sama.

Walaupun dalam perkembangannya, praktek omnibus law dikritik sebagai mekanisme hukum yang terhitung pragmatis dengan beberapa argumentasi sebagai berikut ${ }^{20}$ :

1) Omnibus law mengganti dan merubah norma beberapa UU yang memiliki inisiatif politik yang berbeda. Dalam konteks politik parlementer, yang paling sering diterapkan dalam Negara-negara common law, RUU dapat disampaikan oleh partai-partai mayoritas dan atau partai oposisi. Perbedaan konteks system pemerintahan inilah yang perlu dipertimbangkan, walapun beberapa Negara common law juga ada yang memilih bentuk Negara Republik dan system pemerintahan Presidensiil, dimana eksekutif dan legislatif dapat mengajukan RUU. Dengan dikeluarkannya UU omnibus, parlemen atau lembaga dianggap tidak peka terhadap kompleksitas kepentingan dan aspirasi fraksifraksi yang menyusun dan mengkompromikan kepentingan-kepentingannya dalam UU yang disahkan. Oleh karena itu UU omnibus dianggap tidak demokratis.

2) Omnibus law dianggap tidak disusun secara sistematik karena dalam satu UU omnibus terdapat banyak subyek yang diatur.

Selain itu, dalam konteks Indonesia, di dalam hierarki / tata urutan peraturan perundangundangan di Indonesia sebagaimana diatur di dalam Undang-undang Nomor 12 Tahun 2011 tentang Pembentukan Peraturan Perundang-undangan, belum mengenal konsep omnibus law sebagai salah satu asas dalam sumber hukum. Hal ini menurut penulis tak lebih disebabkan sistem hukum Indonesia yang menganut sistem civil law (Eropa Kontinental) menjadi salah satu penyebab belum dikenalnya konsep omnibus law. Tentu saja salah satu hal krusial yang harus segera direvisi ialah Undang-Undang No. 12 Tahun 2011 tentang Pembentukan Peraturan Perundang-undangan.

Selain itu, ada beberapa kelemahan penerapan konsep ini bila diterapkan, antara lain ${ }^{21}$ :

1) Membuka peluang akan ditolak pada saat paripurna atau di judial review terhadap kebijakan omnibus regulation yang diterbitkan;

2) Legislatif merasa "dikebiri" karena proses pembentukan peraturan perundang-undangan tidak melibatkan legislatif;

${ }^{19}$ Ngo Duc Manh, Omnibus Law-Making Technique And Its Application To The Works Of The National Assembly, Director General of the Center for Information, Library and Research Services, Office Of The National Assembly, 12.

${ }^{20}$ Mirza Satria Buana, Menakar Konsep Omnibus Law ... 311-312.

${ }^{21}$ Firman Freaddy Busroh, Konseptualisasi Omnibus Law ..., 248. 
3) Akan mempengaruhi stabilitas sistem hukum nasional akibat orientasi kebijakan pemerintah yang berubah sesuai kehendak rezim yang memerintah.

RUU semacam ini dipercaya bisa merusak kemampuan anggota parlemen untuk secara bertanggung jawab dan efektif menjalankan tugas mereka untuk memeriksa dan memperdebatkan undang-undang. Pemikiran omnibus law secara tidak langsung membuktikan bahwa proses legislasi selama ini cenderung tidak sehat. Artinya, pembuatan peraturan perundangan cenderung dijadikan target berdasarkan deret kuantitatif, bukan lagi mengutamakan kualitas perundangan yang dihasilkan. Di samping itu juga menunjukkan rendahnya partisipasi dan control masyarakat terhadap proses legislasi.

Omnibus law mengungkap ketegangan paradoksial antara doktrin pemisahan kekuasaan (trias politika) dan prinsip demokrasi serta kepastian hukum ${ }^{22}$. Penghormatan berlebihan pada doktrin pemisahan kekuasaan telah memungkinkan RUU omnibus menjadi ancaman bagi peran legislator serta kredibilitasnya.

Sementara beberapa kalangan akademisi juga ada yang menilai bila konsep omnibus law diberlakukan maka bertentangan dengan sistem hukum civil law. Akan tetapi pertanyaan terbesarnya adalah apakah kita harus terus membiarkan konflik peraturan perundang-undangan dengan resiko menghambat penanaman investasi serta pemasukan pajak sementara resesi dunia 2020 sudah di depan mata?

\section{Omibus Law dalam Tinjauan Hifdzul Mal}

Demi bertahan hidup, manusia memerlukan sesuatu yang dapat memenuhi kebutuhan hidupnya. Maka dari itu manusia membutuhkan harta dan harus berupaya mendapatkannya secara halal dan baik. Segala usaha yang mengarah bagi pencarian harta yang halal dan baik adalah perbuatan yang diperintah oleh syara' ${ }^{23}$. Hal ini sesuai firman Allah SWT:

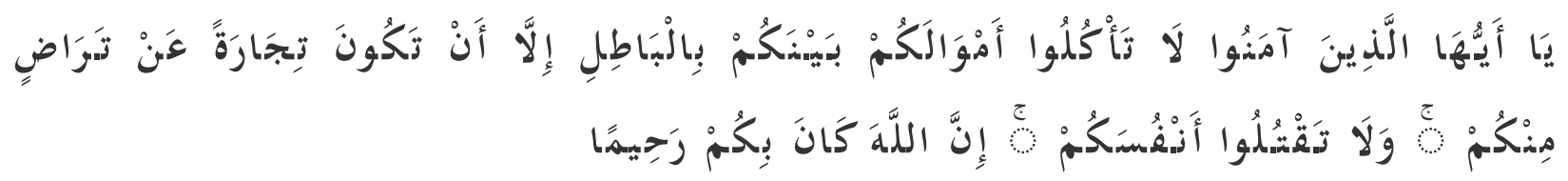

Artinya: Hai orang-orang yang beriman, janganlah kamu saling memakan harta sesamamu dengan jalan yang batil, kecuali dengan jalan perniagaan yang berlaku dengan suka sama-suka di antara kamu. Dan janganlah kamu membunuh dirimu; sesungguhnya Allah adalah Maha Penyayang kepadamu. (Q.S. 4: 29).

Al-Syarbini berpendapat bahwa harta adalah sesuatu yang ada nilai dan orang yang merusakannya akan diwajibkan membayar ganti rugi ${ }^{24}$. Para fuqaha' ada yang mendefinisikan

${ }^{22}$ Adam M. Dodek, Omnibus Bills,..., 1.

${ }^{23}$ Sayyidatul Fitriyah, et. al., Politik Anggaran Pemerintah Daerah Perspektif Maqasid Syari ah: Studi Analisis Sektoral Pada APBD Kabupaten Bangkalan Tahun 2013-2015, Jurnal Ekonomi Syariah Teori dan Terapan, Vol. 4 No. 10 Oktober 2017, 794.

${ }^{24}$ Asy-Syarbini, M. bin A. A.-K. (1978). Mughni al-Muhtaj ila Ma'rifah Ma'ani Alfazh al-Minhaj (Jilid 4). (Beirut, Lebanon: Dar al-Fikr), 246. 
harta sebagai sesuatu yang diingini oleh tabiat manusia dan boleh disimpan untuk tempo yang diperlukan atau sesuatu yang dapat dikuasai, disimpan dan dimanfaatkan ${ }^{25}$.

Harta bisa juga diartikan sebagai hal yang menunjang kehidupan manusia hidup di dunia dan sebagai sarana untuk meraih kebahagiaan di akhirat. Oleh karena itu Islam mengakui hak milik pribadi karena Islam memerintahkan manusia untuk mencari harta yang halal dan melarang praktek riba dan mengambil harta orang lain.

Hingga dapat disimpulkan bahwa yang dimaksud harta adalah sesuatu yang memiliki kriteria sebagai berikut: ${ }^{26}$

a. Dapat disimpan

b. Sesuatu yang dikehendaki munculnya

c. Dapat beredar

d. Dapat dibatasi dengan ukuran tertentu

e. Keadaannya merupakan sesuatu yang diperoleh dari usaha.

Menurut Umar Chapra, harta merupakan kebutuhan yang sangat penting demi memenuhi keempat maqashid yang lain, yaitu hifdzu ad-din (memelihara agama), hifdzu an-nafs (memelihara jiwa), hifdzu al-aql (memelihara akal) dan hifdzu an-nasl (memelihara keturunan). ${ }^{27}$ Masih menurutnya ${ }^{28}$, kewajiban mengelola harta dan modal menjadi lebih kuat bila umat Islam menyadari bahwa Nabi Muhammad SAW sendiri melakukan upaya-upaya produktif dan investasi.

Untuk memelihara konsep harta, Islam mengharamkan praktek mencuri, menipu, memakan riba, merusak harta baik milik sendiri maupun milik orang lain. Untuk memperoleh harta disyaratkan usaha-usaha yang halal, seperti bertani, berdagang, mengelola industri, dan lain sebagainya.

Konsep memelihara harta ini bukan hanya diartikan secara sempit sebagai upaya menjaga harta dari gangguan pencurian, penodongan, atau hak seseorang untuk mendapatkan harta dengan cara yang halal, bekerja. Namun dalam skala yang lebih luas, berupa penegakan atau pemeliharaan sistem ekonomi Islam (ekonomi syari'ah), memelihara hak untuk mendapat pekerjaan dan upah yang layak, penanggulangan kemiskinan, sekaligus mensejahterakan warganya, dan sebagainya.

Perlindungan harta (hifzul-mal) dalam hal ini diterjemahkan ke dalam fungsi ekonomi dalam politik anggaran. Perlindungan harta ini harus diupayakan kesinambungannya dengan membuka cara alternatif yang bersifat berkelanjutan untuk generasi selanjutnya berupa pemanfaatan, distribusi, pertumbuhan dan pemerataan pembangunan. Ini berfungsi sebagai

25 Abidin, I. (1966). Hasyiah Rad al-Mukhtar ala al-Dar al-Mukhtar Sharh Tanwir al-Absar (Jilid 4). (Cairo, Egypt: Matbaah Mustafa al-Halabi), 501.

${ }^{26}$ Muhammad al-Tahir ibn 'Asyur, Maqashid Syar'iyah Al-Islamiyah, (Amman: Darun Nafais, 2001), h. 457-458.

${ }^{27}$ Umer Chapra, The Islamic Vision of Development In The Light of Maqashid Syari'ah, h. 8.

${ }^{28}$ Umer Chapra, Sistem Moneter Islam, (Jakarta: Gema Insani Press, 2000), h. 65 
bahan penting untuk pemenuhan semua empat kebutuhan asasiah lainnya (ad-dharuriyat khamsah).

Memelihara harta ditinjau dari kepentingannya dibagi menjadi tiga peringkat ${ }^{29}$ :

a. Memelihara harta pada tingkatan dharuriyah, seperti disyariatkan tata cara kepemilikan harta melalui jual-beli, kewajiban berusaha mencari nafkah, kewajiban menjaga amanah terhadap harta dan kewenangan yang ia emban, dan disyariatkannya pembagian harta melalui hukum kewarisan. Selain itu diwajibkan pula mengeluarkan zakat apabila harta telah mencapai nishab dan haul. Sebaliknya, syariat Islam melarang mengambil harta orang lain dengan cara yang tidak benar seperti mencuri dan merampok, juga dilarang praktek riba, menipu, memakan harta anak yatim, melakukan suap (risywah). Apabila aturan-aturan ini tidak diindahkan akan menghasilkan kemudaratan yang jelas berkenaan dengan pemeliharaan harta.

b. Memelihara harta pada tingkat hajiyah, seperti disyariatkannya jual beli dengan salam, dibolehkan transaksi sewa-menyewa, utang-piutang, mudharabah, musaqah, dan sebagainya. Sebaliknya, dilarang melakukan monopoli atau menimbun barang perdagangan (ihtikar), dan dilarang melakukan jual beli pada waktu shalat Jum'at. Apabila ketentuan ini tidak dihiraukan, tidak akan merusak kehidupan seseorang berkenaan dengan harta, tetapi membuat kehidupannya yang berhubungan dengan harta, mengalami kendala dan kesulitan. Oleh karena itu, keberadaan aturan-aturan tersebut dibutuhkan untuk memberikan kemudahan dalam kehidupan.

c. Memelihara harta pada tingkatan tahsiniyah, seperti adanya ketentuan syuf'ah dalam melakukan transaksi harta benda, mendorong seseorang untuk bersedekah. Hal ini berupa etika bermuamalah dan sama sekali tidak akan merusak eksistensi kepemilikan harta dan tidak pula menimbulkan kesulitan. Sebaiknya, dilarang melakukan kegiatan mubadzir atau terlalu kikir dengan hartanya, karena sikap boros dan kikir dalam hidup akan menjauhkan dirinya dari kemuliaan.

Hifdzul mal (menjaga harta) ini sangat penting untuk memelihara keseimbangan dan kesinambungan neraca keuangan negara menuju bangsa Indonesia yang sejahtera, adil dan bermartabat. Terlebih dalam mendorong daya dukung pengelolaan kekayaan, aset-aset serta income negara, dibutuhkan upaya terobosan hukum guna memecah kebuntuan hiper-regulasi yang menghambat iklim investasi dan perpajakan.

Islam adalah agama yang pro-investasi, karena di dalam ajarannya, harta yang ada tidak hanya disimpan tetapi harus diproduktifkan, sehingga bisa memberikan manfaat kepada umat. Hal ini berdasarkan firman Allah SWT.:

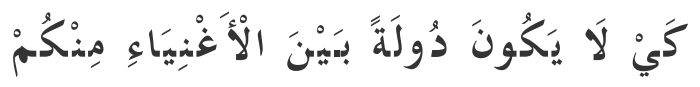

Artinya: "Supaya harta itu jangan beredar di antara orang-orang kaya saja di antara kamu."

${ }^{29}$ Dr. Busyro, M.Ag., Maqashid al-Syari'ah : Pengetahuan Mendasar Memahami Maslahah, Jakarta: Predanamedia Grup, 2019, h. 126-127. 
Praktik investasi juga telah diteladankan oleh Nabi Yusuf yang terekam dalam Q.S. Yusuf (12: 46-49) yang memberi pelajaran bahwa kita sebagai manusia tidak akan mengetahui apa yang akan terjadi di masa yang akan datang, oleh dari itu investasi merupakan langkah antisipatif terhadap hal yang tidak diinginkan. Dalam ayat tersebut dijelaskan bahwa Nabi Yusuf telah melaksanakan investasi untuk jangka waktu tujuh tahun guna menghadapi paceklik.

Selain itu, karena investasi merupakan bagian dari aktivitas ekonomi (muamalah maliyah), sehingga berlaku kaidah fikih, muamalah, yaitu "pada dasarnya semua bentuk muamalah termasuk di dalamnya aktivitas ekonomi adalah boleh dilakukan kecuali ada dalil yang mengharamkannya."(Fatwa DSN-MUI No. 07/DSN-MUI/IV/2000).
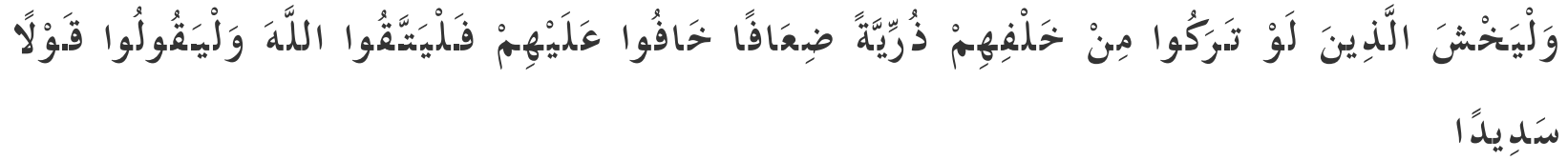

Artinya: "Dan hendaklah takut kepada Allah orang-orang yang seandainya meninggalkan dibelakang mereka anak-anak yang lemah, yang mereka khawatir terhadap (kesejahteraan) mereka. Oleh sebab itu hendaklah mereka bertakwa kepada Allah dan hendaklah mereka mengucapkan perkataan yang benar" (Q.S. 4: 9).

Ayat ini dengan tegas memerintahkan kepada manusia untuk tidak meninggalkan keturunan dalam keadaan lemah, baik lemah moril maupun materil. Secara tersirat ayat ini memerintahkan kepada umat memperhatikan keturunannya dengan mengantisipasi hal yang tidak diinginkan melalui investasi jangka panjang.

Tak hanya itu, Islam juga sangat memperhatikan pemasukan negara dari sektor perpajakan. Dikarenakan sumber dana inilah yang oleh Nabi SAW dijadikan pembiayaan operasional segala kebutuhan negara. Hal ini terbukti dengan disyariatkannya pajak tanah (kharaj), pajak perlindungan (jizyah) dan al-usyur.

Sementara menurut para ulama ${ }^{30}$, alasan utama kebolehan memungut pajak adalah demi kemaslahatan umat, karena bila dana negara yang terbatas tidak mencukupi untuk membiayai berbagai pengeluaran, maka akan timbul kemudharatan. Sementara mencegah kemudaratan adalah suatu kewajiban pula.

Hal ini didukung oleh rekomendasi Munas NU 2012 menyatakan bahwa bagi umat Islam, pungutan yang wajib dibayar berdasarkan perintah langsung dari Al-Quran dan Hadits secara eksplisit adalah zakat. Sedangkan kewajiban membayar pajak hanya berdasarkan perintah yang tidak langsung (implisit) dalam konteks mematuhi penguasa (ulil 'amri), Penguasa di dalam membelanjakan uang Negara yang diperoleh dari pajak berdasarkan kaidah fikih "tasharruful imam 'alai ro'iyyah manuutun bil mashlahah al-raiyyah", mesti mengacu pada tujuan kesejahteraan dan kemanusiaan warga Negara (terutama kaum fakir miskin) ${ }^{31}$.

\footnotetext{
${ }^{30}$ Misalnya Imam Ghazali, al-Mustashfa min 'Ilm al-Ushul, (tt., Darul Kutub Ilmiyyah), 426, Imam Malik, Imam Qurthubi (al-Jami' li Ahkam al-Quran, Jilid 2, (tt, Darul Kutub Ilmiyyah), 242.

${ }^{31}$ https://www.nu.or.id/post/read/39821/inilah-4-rekomendasi-hasil-munas-nu, diakses 20 Desember 2019, pukul 14.01 WIB.
} 
Skema omnibus law perpajakan tentu akan memperlancar sumber utama penerimaan negara ini hingga memperkokoh struktur perekonomian negara. Apalagi kebijakan ini amat relevan ditempuh mengingat Pemerintah sedang getol-getolnya melaksanakan pembangunan infrastruktur yang membutuhkan dukungan dana dari para wajib pajak. Oleh karena itu, RUU omnibus law telah memenuhi kriteria yang dikehendaki maqashid al-syari'ah, dalam hal ini menjaga harta (hifdzul mal) berdasarkan kepada banyaknya kemashlahatan yang diperoleh dari kebijakan tersebut.

Dari hasil penelitian menunjukkan bahwa tujuan dari pembentukan RUU omnibus law adalah dikarenakan ada kebutuhan mendesak untuk teknik merumuskan undang-undang yang mengubah lebih dari satu peraturan yang relevan, demi menciptakan kemaslahatan dan konsistensi berbagai undang-undang. Teknik perumusan ini merupakan salah satu metode yang di satu sisi bertujuan mempercepat kerja legislatif, sementara di sisi lain dalam proses legislasinya terhitung harus sangat terencana dengan reformulasi satu-per-satu.

Lewat omnibus law, dapat menghemat waktu dan mempersingkat proses legislasi dengan menghindari perdebatan di tingkat parlemen yang tidak perlu. Tidak satu demi satu aturan yang direvisi, karena bila UU satu per-satu direvisi akan menimbulkan ego sektoralnya. Mekanisme sederhana dari omnibus law, undang-undang aslinya tetap diberlakukan, tapi materi-materi yang saling bersangkutan dimasukkan dalam satu undang-undang.

Melalui omnibus law, arus masuk investasi bagi kepentingan pembangunan, penciptaan lapangan kerja dan pertumbuhan ekonomi negara dapat meningkat. Perekonomian Negara dapat mencapai efisiensi serta menciptakan iklim investasi yang lebih kompetitif, hingga meningkatkan income Negara secara luas.

Harmonisasi legislasi dan regulasi sangat dibutuhkan demi peningkatan kemudahan berusaha (ease of doing business). Tak hanya itu, usulan omnibus law yang digagas Pemerintah, selain sebagai kesempatan untuk merapikan berbagai peraturan yang tumpang tindih dan mengandung muatan politik yang terkesan konflik satu dengan yang lain, juga berguna sebagai momentum mereformasi peraturan-peraturan lainnya yang menyangkut hajat dan kemaslahatan hidup orang banyak.

Meskipun omnibus law terkesan membuat atau mengubah banyak undang-undang yang berbeda, namun pada dasarnya memiliki satu prinsip atau tujuan dasar yang mengikat semua peraturan dan dengan demikian membuat RUU tersebut dapat dipahami untuk keperluan kemaslahatan bersama.

Setidaknya kehadiran omnibus law dapat diartikan sebagai UU yang dibuat sebagai terobosan hukum demi memecah kebuntuan regulasi demi kepentingan nasional. Hampir semakna, dikisahkan bahwa Umar Bin Khattab pernah melakukan terobosan hukum dengan tidak menerapkan hukum potong tangan secara literal. Padahal berdasarkan Al-Quran (5: 38) dijelaskan bahwa seseorang yang melakukan pencurian (mencapai nishab), harus dikenakan hukuman potong tangan. Ijtihad Umar ini demi memecah kebuntuan hukum menghadapi realita 
masa paceklik dimana sang pencuri melakukan pencurian guna memenuhi kebutuhan dharurinya (karena terpaksa) $)^{32}$.

Pada masa Umar bin Khattab, beliau tidak mengizinkan kaum Muslimin yang berhasil menaklukkan wilayah Syam untuk menguasai lahan tersebut. Artinya tanah atau lahan hasil taklukkan $\left(f a^{\prime} i\right)$ tetaplah hak permanen penduduk lokal, namun hasil dari tanah tersebut diserahkan kepada pihak pemerintah.

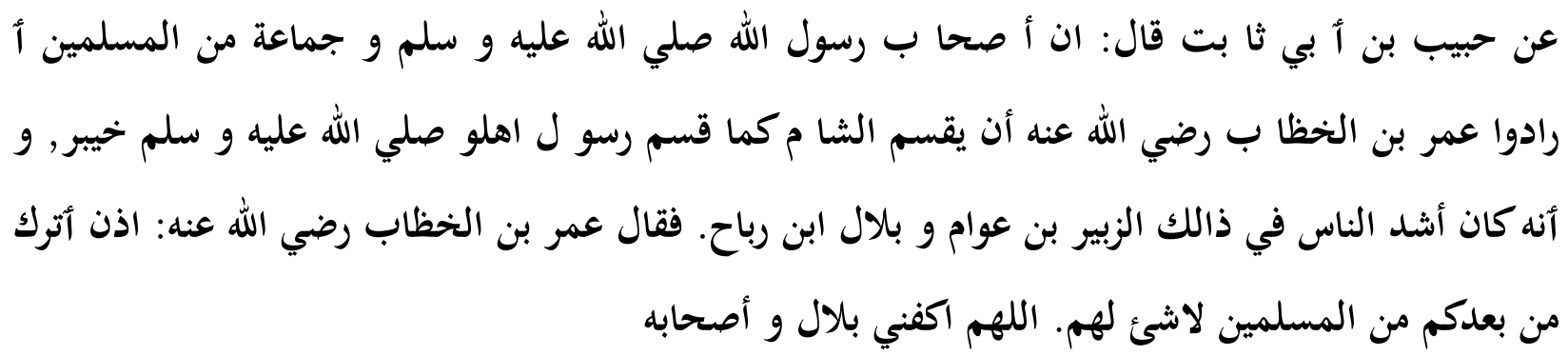

Artinya: Habib ibn Abî Tsabit berkata: Sesungguhnya para sahabat Rasulullah SAW dan sekumpulan kaum Muslim menghendaki agar Umar bin Khathab membagi tanah Syam sebagaimana yang dilakukan oleh Rasulullah SAW terhadap tanah Khaibar. Dan sesungguhnya pihak yang paling menentang keras kebijakan Umar adalah al-Zubair ibn Awam dan Bilal ibn Rabah. Maka dari itu, Umar ibn Khathab berkata: 'Jika aku melakukan hal itu, maka aku akan meninggalkan kaum Muslim setelah kalian sebagai pihak yang tidak memiliki apa-apa. Ya Allah, jagalah aku dari Bilal dan kawankawannya. ${ }^{33}$

Umar menerbitkan kebijakan dengan jalan tidak membagi tanah "sawad" (rampasan) kepada pasukan kaum Muslimin. Tanah tersebut sepenuhnya diserahkan kembali kepada pemilik asalnya. Namun, kepada mereka dibebankan kewajiban membayar usyur. Sementara itu, khalifah Umar hanya membagi tanah kepada kaum Muslimin untuk wilayah yang diperoleh dari jalur perang (unwah) serta memberlakukan kharaj pada tanah tersebut yang dipungut setiap tahunnya dengan besaran yang ditetapkan oleh pemerintah. Perbedaan kebijakan yang diberlakukan antara tanah 'unwah dan tanah sawad inilah yang mengundang kontroversi kala itu dan mengundang perdebatan di kalangan sahabat bahkan menimbulkan pertentangan selama beberapa waktu lamanya.

Kebijakan ini sekilas bertentangan dengan kebijakan Rasul terkait tanah Khaibar. bertujuan agar manfaat dari tanah tersebut bisa dirasakan secara merata dari generasi ke generasi. Inilah kebijakan yang diambil oleh Umar dengan mempertimbangkan maqashid syariah.

Hingga menurut penulis, adanya RUU omnibus law ini menunjukkan gejala dari kekuatan legislatif yang mengalami disfungsi dan sebenarnya upaya hukum ini harus dikurangi untuk mendorong transparansi proses legislatif secara umum. Disebabkan sasaran akhir dari kebijakan

${ }^{32}$ Muhammad ash-Shalabi, The Great Leader of Umar Ibn Khattab, alih bahasa: Khoirul Amru Harahap, cet ke-1, Jakarta: Pustaka al-Kautsar, 2008, h. 342.

${ }^{33}$ Muhammad Akram Khan, Glosarry of Islamic Economics, (London dan New York: Mansell, 1990), 26. 
RUU omnibus law ini adalah menciptakan ekosistem hukum administrasi yang mampu menjamin kesejahteraan rakyat sekaligus perlindungan hukum yang berkeadilan, tidak hanya sekedar kebijakan tambal-sulam.

Penulis lebih memilih Pemerintah segera menerbitkan Rancangan Undang-Undang (RUU) omnibus law terkait kebijakan perpajakan untuk memperkuat perekonomian Indonesia. Kebijakan ini amatlah penting karena demokrasi tanpa peningkatan kesejahteraan rakyat akan semakin kehilangan esensinya. Dengan demikian, rencana Pemerintah melakukan penerapan omnibus law di Indonesia dapat dikatakan sebagai salah satu sarana pemerintah demi mewujudkan maqashid syari'ah dalam meningkatkan perekonomian Negara.

Disebabkan klasifikasi/hierarki maqashid al-syari'ah kontemporer menjadi 3 tingkatan yaitu:

a) General maqashid (maqashid 'ammah) yaitu maqashid yang ditujukan pada keseluruhan hukum Islam termasuk di dalamnya dzaruriyat dan hajiyyat dengan ditambah tujuan maqashid yang baru yaitu keadilan. Oleh sebab itu, maslahat yang primer yang mencakup kewajiban menjaga jiwa, agama, akal, nasab, harta dan kehormatan itu masuk dalam bagian maqashid umum ini. Maqashid 'ammah adalah prinsip general yang ada pada semua atau sebagai besar kondisi tasyri', seperti kebebasan, keadilan dan kemudahan.

b) Partial maqashid (maqashid juz'iyyat) yaitu maqasid yang paling substantif dalam peristiwa hukum. Maslahah ini juga disebut rahasia atau hikmah (asrar). Permisalan maqashid ini adalah maksud dari rukhsah tidak puasa bagi yang tidak mampu ialah meminimalisir masyaqqat. Kebutuhan akan unsur kejujuran dan kuatnya ingatan dalam kesaksian. Dalam kriminal modern bisa jadi cukup dengan satu saksi adil dan tidak wajib ada dua saksi asal yang bersangkutan mampu memperlihatkan data yang valid dan sikap jujur. ${ }^{34}$

c) Specific maqashid (maqashid khassah) yaitu maqasid yang terhubung pada maslahah dalam problem tertentu, misalnya tidak boleh melukai perempuan dalam lingkup keluarga, dan tidak boleh menipu dalam perniagaan lewat apapun, dalam bab jinayat yang bertujuan membuat efek jera. ${ }^{35}$

Bila dicermati, maka kebijakan omnibus law dalam perspektif maqashid syari'ah (hifdzul mal) dapat digambarkan sebagai berikut:

${ }^{34}$ Retna Gumanti, Maqashid Syari'ah Menurut Jasser Auda (Pendekatan Sistem dalam Hukum Islam), Jurnal al-Himayah, Vol. 2 No. 1 Maret 2018, h. 113.

${ }^{35}$ Retna Gumanti, Maqashid Syari'ah........., h. 5 


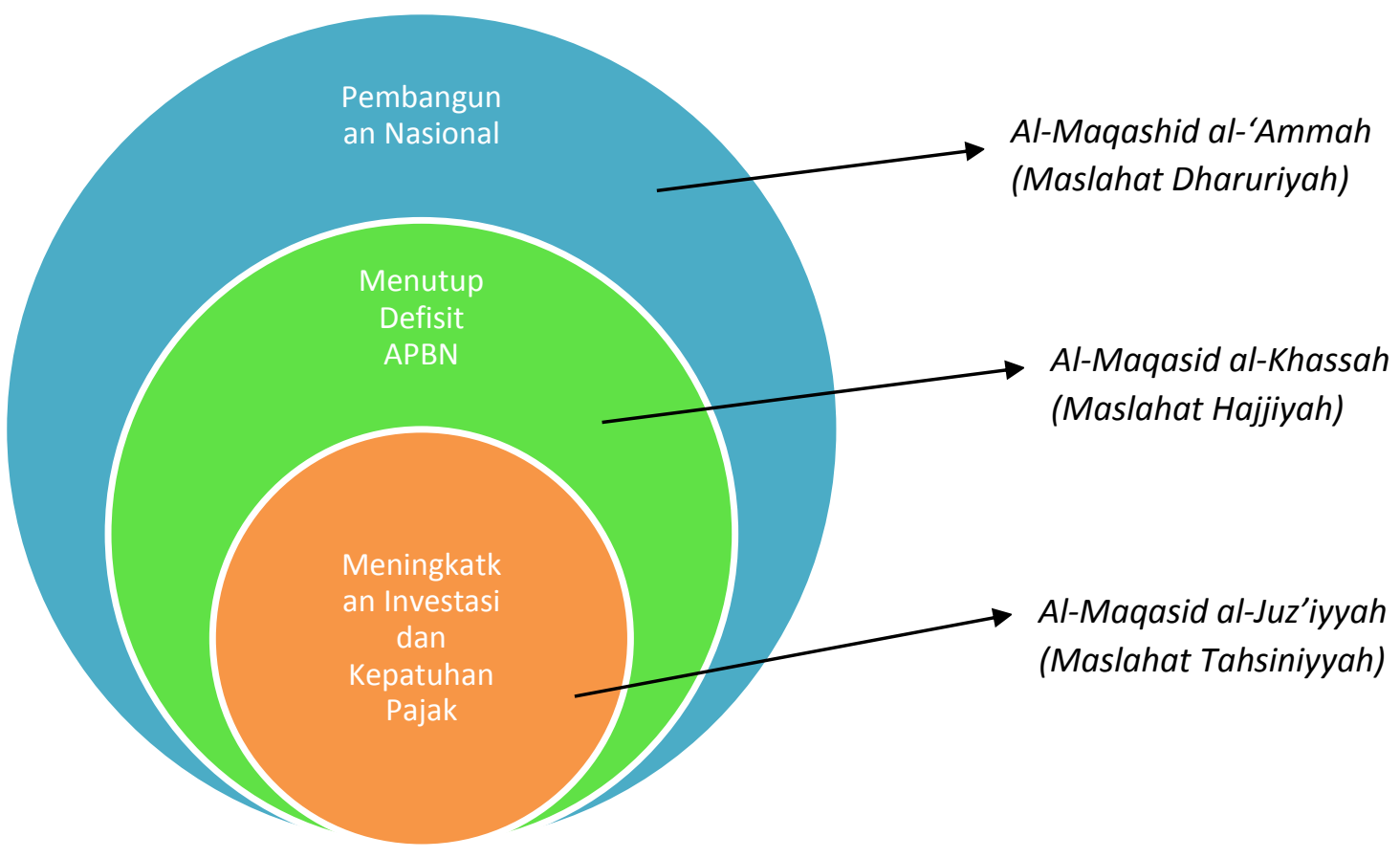

Gb. 1

\section{Penutup}

Maqashid Omnibus Law

Melalui gagasan konsep omnibus law diharapkan dapat menyelesaikan konflik regulasi di bidang investasi dan perpajakan serta diharapkan efektif menyelesaikan disharmoni peraturan perundangan yang telah lama mendera dan akibatnya timbul mal-administrasi yang bisa berujung kepada kriminalisasi pejabat.

Adapun kelebihan penerapan omnibus law antara lain, mengatasi konflik peraturan perundang-undangan secara efektif dan efisien serta cepat, menunjang iklim investasi, pengurusan perizinan investasi bisa lebih terpadu, meningkatnya hubungan koordinasi antar instansi terkait, mampu memutus rantai birokrasi menjadi sederhana, serta adanya jaminan kepastian hukum dan perlindungan hukum bagi para pengambil kebijakan.

Sementara kendala yang dihadapi antara lain, membuka peluang akan ditolak pada saat paripurna melalui judial review terhadap kebijakan omnibus regulation, sebab pihak legislatif merasa dikebiri karena proses pembentukan peraturan perundang-undangan tidak melibatkan legislatif sepenuhnya.

Hasil penelitian menunjukan bahwa penerapan konsep omnibus law sebagai solusi atas fenomena hiperregulasi di Indonesia. Hiperregulasi tersebut memberikan beban dalam melakukan sinkronisasi dan harmonisasi peraturan perundang-undangan. Kebijakan ini juga mendapatkan legitimasi Umar bin Khattab pernah melakukan terobosan hukum dengan tidak menerapkan hukum potong tangan secara literal. Umar juga pernah berijtihad tidak membagikan tanah Syam dengan mempertimbangkan kemanfaatan tanah tersebut. Kehadiran omnibus law 
selayaknya ditujukan demi mewujudkan keadilan, kesejahteraan umum dan melindungi hak individu.

\section{DAFTAR PUSTAKA}

Dodek, Adam M., Omnibus Bills: Constitutional Constraints and Legislative Liberations, Ottawa Law Review, Vol. 48, No. 1, 2017.

Duhaime Legal Dictionary, http://www.duhaime.org/LegalDictionary/O/OmnibusBill.aspx

Fitriyah, et. al., Sayyidatul, Politik Anggaran Pemerintah Daerah Perspektif Maqasid Syari ah: Studi Analisis Sektoral Pada APBD Kabupaten Bangkalan Tahun 2013-2015, Jurnal Ekonomi Syariah Teori dan Terapan, Vol. 4 No. 10 Oktober 2017.

Al-Ghazali, Abu Hamid, al-Mustashfa min 'Ilm al-Ushul, tt., Darul Kutub Ilmiyyah.

Gumanti, Retna, Maqashid Syari'ah Menurut Jasser Auda (Pendekatan Sistem dalam Hukum Islam), Jurnal al-Himayah, Vol. 2 No. 1 Maret 2018.

Ibn Asyur, Muhammad al-Tahir, Maqashid Syar'iyah Al- Islamiyah, (Amman: Darun Nafais, 2001).

Khan, Muhammad Akram, Glosarry of Islamic Economics, London dan New York: Mansell, 1990.

Manh, Ngo Duc, Omnibus Law-Making Technique And Its Application To The Works Of The National Assembly, Director General of the Center for Information, Library and Research Services, Office Of The National Assembly.

Massicotte, Louis, Omnibus Law in Theory and Practice, Canadian Parliamentary Review, 2013.

Philiphus M, Hadjon, 2007, Perlindungan Hukum Bagi Rakyat di Indonesia, Sebuah Studi tentang Prinsip-Prinsipnya, Penanganannya oleh Pengadilan dalam Lingkungan Peradilan Umum dan Pembentukan Peradilan Administrasi, Peradaban.

Qamar, Nurul, 2010. Perbandingan Sistem Hukum dan Peradilan Civil Law System dan Common Law System. Makassar: Pustaka Refleksi.

Al-Qurthubi, Imam, al-Jami’li Ahkam al-Quran, Jilid 2, tt, Darul Kutub Ilmiyyah.

Toruan, Henry Donald Lbn., Pembentukan Regulasi Badan Usaha Dengan Model Omnibus Law, Jurnal Hukum Tora Fakultas Hukum Universitas Kristen Indonesia, Vol. 3 No. 1, April 2017.

https://www.bkpm.go.id/.

https://www.nu.or.id/post/read/39821/inilah-4-rekomendasi-hasil-munas-nu. 